\title{
Understanding barriers to utilization of 17-hydroxyprogesterone caproate and other interventions to prevent preterm birth in Fresno County, California
}

\author{
Subhashini Ladella ${ }^{1}$ (D) , Amber Shaver ${ }^{2}$ (D), Tania Pacheco-Werner ${ }^{3}$ (D), Cynthia Cortez ${ }^{4}$ (D) , \\ Mallory Novack ${ }^{4}$ (iD), Andrea Wiemann ${ }^{3}$ iD, Miriam Kuppermann ${ }^{5}$ \\ ${ }^{1}$ Department of Obstetrics \& Gynecology, Maternal Fetal Medicine, University of California San Francisco-Fresno, Fresno, CA, USA \\ ${ }^{2}$ Fresno Department of Psychology, California State University, Fresno, CA, USA \\ ${ }^{3}$ Fresno Central Valley Health Policy Institute, California State University, Fresno, CA, USA \\ ${ }^{4}$ Department of Obstetrics, Gynecology \& Reproductive Sciences, University of California San Francisco, San Francisco, CA, USA \\ 'Department of Obstetrics \& Gynecology, University of California San Francisco-Fresno, Fresno, CA, USA
}

\begin{abstract}
Objective: Preterm birth is one of the leading causes of neonatal morbidity and mortality. A history of prior spontaneous preterm birth is a known risk factor for recurrent preterm birth. While 17alpha-hydroxyprogesterone caproate (17P) has been found in some studies to reduce recurrent preterm birth by $34 \%$, many women who could have benefited from its use did not receive this intervention. We sought to investigate the rate of and reasons for underutilization of $17 \mathrm{P}$ in Fresno County, California, where the preterm birth rate trend from 2017 and recent 2020 data showed a significantly higher rate at $10.1 \%$ and $9.8 \%$ respectively, when compared to the state average of $8.6 \%$ and $8.8 \%$ respectively.

Methods: We conducted a retrospective chart review of patients who delivered at Community Regional Medical Center in Fresno from January to December 2016, and surveys of providers and patients, to help identify barriers to $17 \mathrm{P}$ utilization.

Results: After controlling for age, body mass index, interpregnancy interval, and race/ethnicity, we determined that women who had private insurance were 3 times more likely to have received $17 \mathrm{P}$ compared to women with public insurance (adjusted odds ratio 2.97, 95\% CI: $1.6-6.51, \mathrm{p}<.001)$. We also found that only $23.3 \%$ of patients eligible for $17 \mathrm{P}$ actually received this intervention. The surveys identified difficulty with completing the insurance approval process and receiving the treatment within the clinically recommended timeline as primary barriers to $17 \mathrm{P}$ utilization.

Conclusion: This study confirmed that $17 \mathrm{P}$ intervention for prevention of recurrent preterm birth was underutilized and disproportionately affected patients with inadequate prenatal care and those who had public insurance.
\end{abstract}

Keywords: Preterm birth, prevention, intervention barriers, 17OHP.
Özet: Fresno County, Kaliforniya'da preterm doğumu önlemek için 17-hidroksiprogesteron kaproat ve diğer girişimlerden faydalanmanın önündeki engelleri anlamak

Amaç: Preterm doğum, neonatal morbidite ve mortalitenin önde gelen sebeplerinden biridir. Spontan preterm doğum geçmişi, rekürran preterm doğum için bilinen bir risk faktörüdür. Bazı çalışmalarda 17alfa-hidroksiprogesteron kaproatın (17P) rekürran preterm doğumu \%34 azalttğı̆ bulunsa da, kullanımından faydalanamamış birçok kadına bu girişim uygulanmamıştır. Kalifroniya'daki Fresno County'deki preterm doğum oranı ile ilgili 2017 yllındaki eğilimi ve yeni 2020 yılı verileri (sırasılyla \% 10.1 ve \%9.8), eyaletin aynı yllar için kaydedilen sirasılla $\% 8.6$ ve $\% 8.8$ 'lik verileri ile karş̧laştrrildığında anlamlı bir şekilde daha yüksektir. Bu nedenle Fresno County'de, 17P'nin az kullanımının oranlarını ve amaçlarını araşırımayı amaçladık.

Yöntem: 17P kullanımına yönelik engelleri tespit etmeye yardımcı olması amacıyla 2016 Ocak - Aralık ayları arasında Fresno'daki Community Regional Medical Center'da doğum yapan hastaların çizelgelerini retrospektif olarak inceledik ve hizmet sağlayıcılar ile hastaların katıldı̆̆ı anketler yaptık.

Bulgular: Yaş, vücut kitle indeksi, gebelikler arası aralık ve ırk/ etnik köken yönünden kontrol ettikten sonra, özel sigortası olan kadınların devlet sigortası olanlara kıyasla 3 kat daha fazla $17 \mathrm{P}$ aldıklarını belirledik (düzeltilmiş olasılık oranı 2.97, \%95 GA: 1.6-6.51, p<.001). Ayrıca, 17P'ye uygun olan hastaların yalnızca \%23.3'üne bu girişimin uygulandığını bulduk. Anketler, sigorta onay sürecini tamamlamanın ve klinik olarak tavsiye edilen süre içinde tedavi almanın zorluğunun 17P kullanımının önündeki ana engeller olduğunu ortaya koymuştur. Sonuç: Çalışmamız, rekürran preterm doğumun önlenmesi için $17 \mathrm{P}$ girişiminin yetersiz şekilde kullanıldığını ve bu durumun eksik prenatal bakım alan ve devlet sigortası olan hastaları orantısız şekilde etkilediğini doğrulamıştır.

Anahtar sözcükler: Preterm doğum, önleme, girişim engelleri, 17OHP.

Correspondence: Subhashini Ladella, MD. Department of Obstetrics \& Gynecology, University of California San Francisco-Fresno, Fresno, CA, USA. e-mail: Subhashini.Ladella@ucsf.edu / Received: June 1, 2021; Accepted: August 1, 2021

How to cite this article: Ladella S, Shaver A, Pacheco-Werner T, Cortez C, Novack M, Wiemann A, Kuppermann M. Understanding barriers to utilization of 17-hydroxyprogesterone caproate and other interventions to prevent preterm birth in Fresno County, California. Perinatal Journal 2021;29(2):155-164. doi:10.2399/prn.21.0292011

ORCID ID: S. Ladella 0000-0001-7821-5288; A. Shaver 0000-0001-6914-3833; T. Pacheco-Werner 0000-0002-8766-9115; C. Cortez 0000-0001-7305-338X; M. Novack 0000-0003-3659-1001; A. Wiemann 0000-0002-9722-9471; M. Kuppermann 0000-0002-8074-6923 


\section{Introduction}

Preterm birth, defined as delivery before 37 weeks gestation, is among the leading causes of neonatal morbidity and mortality. ${ }^{[1]}$ Approximately, 1 in 10 babies are born preterm in the United States each year with annual estimated costs of $\$ 26.2$ billion as was last reported in 2007 , that included medical and non-medical costs. ${ }^{[2]}$ The national preterm birth rate increased from $9.57 \%$ in 2014 to $10.02 \%$ in $2018 .^{[3,4]}$ According to the 2020 birth statistics data, in Fresno County, California, the preterm birth rate has been significantly higher at $9.8 \%$ compared to the state average of $8.8 \%$. $^{[5]}$

Risk factors for preterm birth include prior spontaneous preterm birth, multiple gestations, assisted reproductive techniques, and short cervical length. ${ }^{[6]}$ African American women have nearly double the risk of having a preterm birth, contributory factors being racial discrimination and systemic inequality. ${ }^{[7]}$ Other risk factors include maternal infections, anemia, hypertension, diabetes, short inter-pregnancy interval, vaginal bleeding, smoking, drug abuse, young maternal age, fetal and placental abnormalities, and psychosocial stressors. ${ }^{[6]}$ Despite these identifiable risk factors, numerous barriers limit patients' access to early recognition, treatments and interventions. These barriers include but are not limited to inadequate prenatal care, gaps in communication between providers and patients, systemic racism and socio-cultural barriers that inhibit women from seeking care. ${ }^{[8]}$

Progesterone has long been known to have an inhibitory effect on uterine contractility and is thought to play a key role in the protection of pregnancy until term gestation. In 2003, the results of a multicenter placebo controlled randomized trial published by Meis et al., reported a $34 \%$ reduction of recurrent preterm birth with weekly $17 \mathrm{P}$ injections in women with a history of prior spontaneous preterm birth (SPTB). ${ }^{[0]}$ Based on these findings, the Society for Maternal-Fetal Medicine (SMFM) and American Congress of Obstetrics and Gynecology (ACOG) endorsed and recommended the use of $17 \mathrm{P}$ for prevention of recurrent preterm birth in women with a singleton gestation with a prior obstetrical history of spontaneous preterm birth. ${ }^{[10]}$

Subsequently, after the completion of our study, there has been a recent mixed evidence and controversy regarding the effectiveness of $17 \mathrm{P}$ based on the PRO-
LONG study, published in 2019. In response to the PROLONG study results and the FDA decision, the SMFM issued a statement in support of continued use of $17 \mathrm{P}$ for the high risk patient population following an informed shared decision making between the provider and patients. The ACOG Practice Advisory has also endorsed the SMFM response. ${ }^{[1-13]}$ In addition, a recent SMFM statement issued in March 2021, supported and recommended the use of $17 \mathrm{P}$ in women with a singleton gestation and a history of prior SPTB between 20 and 36 6/7 weeks of gestation in response to the published results of "Evaluating Progestogens for Preventing Preterm birth International Collaborative (EPPPIC): meta-analysis of individual participant data from randomized controlled trials". ${ }^{[1,15]}$

In Fresno County, California, as elsewhere, persistent racial health disparities exist with the highest preterm birth rate reported in African Americans (11.9\%) and the lowest in the White population (7.7\%). Moreover, while only $5.6 \%$ of infants born in Fresno County are African American, they represent $25.3 \%$ of infant deaths. ${ }^{[16]}$ Although the specific reason for the higher rate of preterm delivery among African Americans in Fresno County is unknown, underutilization of $17 \mathrm{P}$ intervention for women with a history of preterm birth may play a role. ${ }^{[17]}$ Previous research has shown that less than half of eligible women actually received the intervention. ${ }^{[18]}$ Barriers can exist at multiple levels of care that include system barriers, provider-related barriers, and patientlevel barriers. Some of these barriers include lack of access to early prenatal care, provider/patient's lack of knowledge, administration and patient-related costs, ability for compounding, time and appointment commitments, and potential adverse reactions to the medication. ${ }^{[19,20]}$ In addition, prenatal care is now being offered by a variety of medical personnel, some of whom may not be aware of available interventions. ${ }^{[18,21]}$

Due to the significantly increased rate of preterm birth in Fresno County, we sought to investigate 17P utilization and understand the barriers to underutilization of $17 \mathrm{P}$ among eligible women. In addition, we studied the use of other evidence-based interventions including cerclage for cervical incompetence and vaginal progesterone for short cervix. Specifically, our goals were to: (1) understand the number of women who were eligible, were offered, and received $17 \mathrm{P}$ and other interventions and (2) understand provider, patient and system level barriers to accessing these treatments. 


\section{Methods}

We conducted a retrospective chart review of patients who gave birth at the medical center included for our study from January to December 2016. The medical center studied is one of the largest Medi-Cal obstetrical providers in the county, with approximately 5000 deliveries each year.

The data was abstracted from patient's electronic medical records (EMR). Due to the discrepancies and limitations of EMR documentation of diagnosis codes referring to prior preterm birth history, our initial screening and review included all those with a prior preterm delivery diagnosis code, and current preterm delivery diagnosis code. This was done to ensure we did not miss patients in the category of prior preterm birth. Therefore, a total of 1294 patient's charts that were initially identified, screened and reviewed included prior and current preterm delivery diagnosis codes.

The detailed retrospective chart review and data analysis included all singleton pregnancies eligible for $17 \mathrm{P}$ based on history of prior spontaneous preterm birth following spontaneous preterm labor and/or history of premature preterm rupture of membranes resulting in preterm delivery prior to 37 weeks gestation.

Exclusion criteria applied to the sample of medical records involved medically indicated preterm births, multiple gestations, and fetal anomalies. Seven charts were also excluded upon review, one due to lack of $17 \mathrm{P}$ documentation and six others due to absence of current or previous preterm birth.

The detailed data abstraction from the electronic medical records included demographic characteristics (maternal age, race/ethnicity, insurance provider), clinical characteristics (body mass index [BMI], interpregnancy interval, presence of short cervix), prenatal care details (prenatal care initiation; receipt of $17 \mathrm{P}$, vaginal progesterone, antibiotics, and/or cerclage), and birth outcomes (gestational age [GA] at delivery, infant birth weight and Apgar scores).

In addition, in order to assess operational and structural barriers that prevent eligible women from receiving $17 \mathrm{P}$ and other evidence-based interventions, patient and provider surveys were conducted. Fifteen patients who delivered preterm during the study period were randomly selected. These women were interviewed over the telephone by a study staff member using a scripted questionnaire.
Provider surveys were administered to prenatal care providers, that included physicians, licensed vocational nurses, medical assistants, nurse practitioners, and physician assistants, who were responsible for the majority of deliveries at the medical center included in our study. The provider survey comprised of questions about screening for preterm birth risk and knowledge of available interventions and the process for implementation of the prescribed interventions.

Participation in the survey component of the study was completely voluntary, with assurance that all responses would be anonymous and that there would be no impact on current/future health care nor employment. Forty-one survey responses were received.

The surveys were created and screened by the research team workgroup that included obstetrical providers, a perinatologist, public health nurse and maternal child health research investigators. The survey questionnaire was constructed and modified from other standardized surveys used across the country in similar research about $17 \mathrm{P}$ or other preterm birth interventions. ${ }^{[2,23]}$ Data entry was done through Qualtrics and all surveys were analyzed using STATA (StataCorp LLC, College Station, TX, USA) and SPSS (IBM Corp., Armonk, NY, USA).

Multivariate models were used to explore associations between maternal characteristics and 17P utilization. Maternal characteristics were analyzed using chisquare to identify differences between those that received the intervention and those that did not. In addition, multiple regression was used to obtain adjusted odds ratios for the mothers that received $17 \mathrm{P}$ and their preterm birth outcomes.

\section{Results}

Out of the total 1294 women included in our chart review, 599 (46.3\%) had a history of preterm delivery, and $695(53.7 \%)$ had a current preterm delivery that occurred during the study period due to the EMR documentation discrepancies in the diagnosis codes. Among the sample of patients with history of previous preterm delivery, 378 (63.1\%) had a prior spontaneous preterm birth and met the eligibility criteria for the $17 \mathrm{P}$ intervention. Maternal characteristics of women who had a previous spontaneous preterm birth were compared by the receipt of the $17 \mathrm{P}$ intervention. As summarized in 
Table 1. The association between the characteristics of mothers with history of spontaneous PTD (S-PTD) and 17P intervention.

\begin{tabular}{|c|c|c|c|c|c|c|c|c|}
\hline \multirow[b]{2}{*}{ Maternal characteristics } & \multirow{2}{*}{$\begin{array}{c}\begin{array}{c}\text { All prior S-PTD } \\
\mathrm{n}=378\end{array} \\
n\end{array}$} & \multicolumn{2}{|c|}{$\begin{array}{l}\text { Intervention received } \\
\qquad \mathrm{n}=\mathbf{8 8}(\mathbf{2 3 . 3} \%)\end{array}$} & \multicolumn{3}{|c|}{$\begin{array}{l}\text { Chi-square test of } \\
\text { independence }\end{array}$} & \multicolumn{2}{|c|}{$\begin{array}{l}\text { Intervention not received } \\
\qquad \mathrm{n}=\mathbf{2 9 0}\end{array}$} \\
\hline & & $\mathbf{n}$ & $\%$ & $\mathrm{n}^{*}$ & Chi & p & $\mathbf{n}$ & $\%$ \\
\hline Maternal age & & & & 378 & 0.082 & 0.774 & & \\
\hline$<35$ years & 334 & 77 & 23.1 & & & & 257 & 77.0 \\
\hline $35+$ years & 44 & 11 & 25 & & & & 33 & 75.0 \\
\hline BMI & & & & 338 & 0.028 & 0.867 & & \\
\hline$<35 \mathrm{BMI}$ & 274 & 70 & 25.6 & & & & 204 & 74.5 \\
\hline $35+\mathrm{BMI}$ & 64 & 17 & 26.6 & & & & 47 & 73.4 \\
\hline Bilinmiyor & 40 & 1 & 2.5 & & & & 39 & 97.5 \\
\hline Short IPI $¥$ & & & & 348 & 6.496 & 0.011 & & \\
\hline$<18$ months & 164 & 29 & 17.7 & & & & 135 & 82.3 \\
\hline $18+$ months & 184 & 54 & 29.4 & & & & 130 & 70.7 \\
\hline Unknown & 30 & 5 & 16.7 & & & & 25 & 83.3 \\
\hline Maternal race/Ethnicity & & & & 370 & 7.003 & 0.072 & & \\
\hline AIAN & 3 & 0 & 0 & & & & 3 & 100.0 \\
\hline Asian & 49 & 11 & 22.5 & & & & 38 & 77.6 \\
\hline Black/AA & 49 & 6 & 12.2 & & & & 43 & 87.8 \\
\hline Hispanic or Latina & 216 & 49 & 22.7 & & & & 167 & 77.3 \\
\hline Native Hawaiian / PI & 3 & 2 & 66.7 & & & & 1 & 33.3 \\
\hline White & 56 & 19 & 33.9 & & & & 37 & 66.1 \\
\hline Unknown & 2 & 1 & 50 & & & & 1 & 50.0 \\
\hline Insurance payer status ${ }^{\ddagger}$ & & & & 366 & 13.404 & 0.0002 & & \\
\hline Public & 321 & 64 & 19.9 & & & & 257 & 80.1 \\
\hline Private & 45 & 20 & 44.4 & & & & 25 & 55.6 \\
\hline Out of Pocket & 12 & 4 & 33.3 & & & & 8 & 66.7 \\
\hline Prenatal care received $^{\dagger}$ & & & & 368 & 6.297 & 0.012 & & \\
\hline Yes & 349 & 88 & 25.2 & & & & 261 & 74.8 \\
\hline No & 19 & 0 & 0 & & & & 19 & 100.0 \\
\hline Unknown & 10 & 0 & 0 & & & & 10 & 100.0 \\
\hline Prenatal care initiation ${ }^{\ddagger}$ & & & & 223 & 10.973 & 0.004 & & \\
\hline First trimester & 231 & 73 & 31.6 & & & & 158 & 68.4 \\
\hline Second trimester & 62 & 10 & 16.1 & & & & 52 & 83.9 \\
\hline Third trimester & 13 & 0 & 0 & & & & 13 & 100.0 \\
\hline Unknown & 72 & 5 & 6.9 & & & & 67 & 93.1 \\
\hline Total & 378 & 88 & 23.3 & & & & 290 & 76.7 \\
\hline
\end{tabular}

* Low $n$ or unknown categories in grey were not included in the chi-square comparisons. ${ }^{+}$Indicates significant chi-square test of independence $(p<0.05)$ when

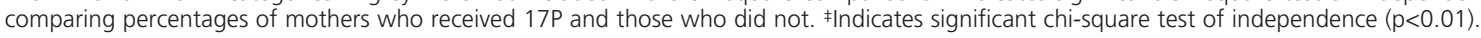

Table 1, out of these 378 eligible women, $88(23.3 \%)$ received $17 \mathrm{P}$.

In our study group, greater utilization of $17 \mathrm{P}$ was noted in women who received prenatal care $(\mathrm{n}=88$, $25.2 \%)$ when compared to women with no prenatal care $(\mathrm{n}=19,0 \%, \mathrm{p}<0.05)$. The intervention was received more frequently by women who initiated prenatal care (PNC) in the first trimester $(31.6 \%)$ than for women who initi- ated PNC in the second (16.1\%) or third trimester when they missed the GA window of receiving $17 \mathrm{P}(\mathrm{p}<0.01)$.

Association of $17 \mathrm{P}$ treatment was higher in the group of women who had an interpregnancy interval of 18 months or more (29.4\%) compared to women who had an interpregnancy interval of less than 18 months $(17.7 \%, \mathrm{p}<0.05)$. In addition, the utilization of $17 \mathrm{P}$ was greater in the women with private insurance $(44.4 \%)$ 
Table 2. Adjusted odds ratios for the association between selected maternal characteristics with the receipt of 17P ( $n=358)$.

\begin{tabular}{|c|c|c|c|c|}
\hline Maternal characteristics & aOR & $95 \% \mathrm{Cl}$ lower & $95 \% \mathrm{Cl}$ upper & p-value \\
\hline Maternal age $35+$ & 1.169 & 0.518 & 2.64 & 0.707 \\
\hline BMI 35+ & 1.152 & 0.591 & 2.244 & 0.678 \\
\hline Short IPI $<18$ months & 0.682 & 0.394 & 1.18 & 0.171 \\
\hline \multicolumn{5}{|l|}{ Maternal race/Ethnicity } \\
\hline Asian & 0.56 & 0.216 & 1.451 & 0.233 \\
\hline Black or African American & 0.356 & 0.111 & 1.14 & 0.082 \\
\hline Hispanic or Latina & 0.661 & 0.317 & 1.376 & 0.268 \\
\hline White & REF & & & \\
\hline \multicolumn{5}{|l|}{ Insurance payer status } \\
\hline Public & REF & & & \\
\hline Private* & 2.739 & 1.281 & 5.855 & 0.009 \\
\hline
\end{tabular}

*Indicates significance at $p<0.01$. aOR: adjusted odds ratio; REF: reference category.

compared to those who had public insurance $(19.9 \%$, $\mathrm{p}<0.001)$.

Multivariate logistic regression analysis was performed for maternal age, BMI, inter-pregnancy interval (IPI), ethnicity, and insurance status (Table 2). Our results show that those with private insurance are more than twice as likely to receive $17 \mathrm{P}$ than those with public insurance, $(\mathrm{aOR}=2.74,95 \% \mathrm{CI}: 1.98-6.51, \mathrm{p}=0.009)$.

A summary of various treatments received by mothers with a history of SPTD is shown in Table 3. Out of the total 378 mothers who had a history of SPTD, $121(32.0 \%)$ received one or more of the three interventions $(17 \mathrm{P}$, vaginal progesterone, or cerclage). Among these, 78 (20.6\%) of mothers with a history of SPTD received $17 \mathrm{P}$ alone and 88 (23.3\%) either received $17 \mathrm{P}$ alone, $17 \mathrm{P}$ and cerclage, or $17 \mathrm{P}$ and vaginal progesterone. Only a very small percentage of $(2.7 \%)$ received $17 \mathrm{P}$ with other interventions. The total number of mothers who did not receive any intervention or treatment was $257(68.0 \%)$.

Among the 378 women who were eligible for $17 \mathrm{P}$, 290 women (76.7\%) did not receive 17P (Table 1). Fig. 1 shows the frequency of the multiple reasons the eligible women did not receive $17 \mathrm{P}$, as documented in the electronic medical records $(\mathrm{n}=290)$. The most commonly reported reasons they did not receive the intervention included missing the eligible time frame (14.8\%), treatment declined by patients $(6.2 \%)$, or denial of insurance approval (2.8\%). However, $73.5 \%$ had no documented reason or an unknown reason for not receiving the intervention in their medical records.
The process and barriers of receiving $17 \mathrm{P}$, as informed by the provider survey and chart review are mapped out in Fig. 2. The provider survey included multiple types of healthcare providers; physicians made up $32 \%(n=13)$ of the sample population of providers that were surveyed, and the remainder were other clinical staff and office managers. Provider survey responses (Fig. 2) for not prescribing 17P for eligible women included lack of knowledge about the intervention $(17 \%)$, patient's late entry to care $(15 \%)$, lack of adequate evidence about the effectiveness of $17 \mathrm{P}$ in preterm birth prevention (5\%), and patients non-compliance to treatment $(5 \%)$.

\section{Discussion}

Our study results showed that out of the total 378 women who were eligible for $17 \mathrm{P}, 76.7 \%(\mathrm{n}=290) \mathrm{did}$ not receive $17 \mathrm{P}$ intervention. In order to obtain the full

Table 3. Intervention summary for mothers with a previous spontaneous PTD.

\begin{tabular}{lcc} 
Intervention type & $\mathbf{n}$ & $\%$ \\
17P only & 78 & 20.6 \\
Vaginal progesterone only & 14 & 3.7 \\
Cerclage only & 15 & 4.0 \\
$17 \mathrm{P}$ and cerclage & 7 & 1.9 \\
$17 \mathrm{P}$ and vaginal progesterone & 3 & 0.8 \\
Cerclage and vaginal progesterone & 4 & 1.1 \\
None & 257 & 68.0 \\
Total & 378 & \\
\hline
\end{tabular}




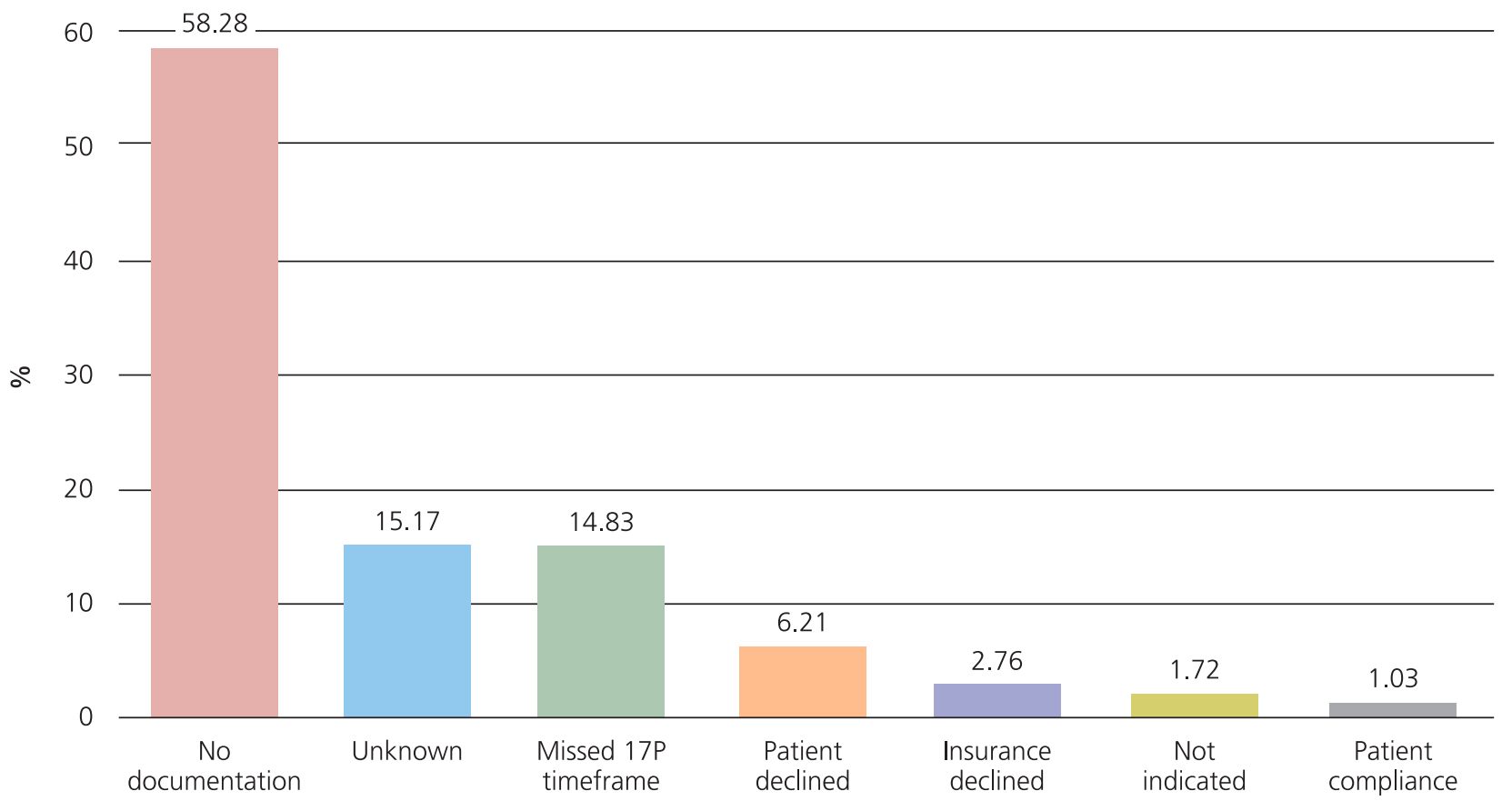

Fig. 1. Reasons eligible patients (history of spontaneous preterm delivery) did not receive 17P.

benefit of $17 \mathrm{P}$, eligible women have to navigate a path that has many roadblocks related to provider, patient and system barriers. The first step in the process that is a major limiting factor is the identification of at-risk mothers followed by the gestational age for onset of prenatal care. Pregnant mothers who presented late to prenatal care missed the window of opportunity for interventions to be implemented. Late prenatal care identified here as a major limiting factor has been reported by Cross-Barnet et al., as a significant reason for under-utilization of $17 \mathrm{P}$ in the Medicaid patient population. ${ }^{[2]}$ Although many studies have looked at the efficacy of $17 \mathrm{P}$ in preterm birth prevention, very few studies have looked at understanding the potential barriers to the utilization of $17 \mathrm{P}$. Effective utilization of $17 \mathrm{P}$ depends on factors at various levels of care that involves patients, providers and the healthcare system.

\section{Barriers to utilization}

Among the eligible women, $73.5 \%$ with no had no documented reason or an unknown reason for not receiving the intervention in their medical records may indicate incomplete documentation by providers or lack of detailed discussion addressing the beneficial use of $17 \mathrm{P}$. It may also indicate problems with discrepancies in the documentation in the electronic medical records system in use at the medical institution of study.

During the initial prenatal encounter visit, not all patients may have been screened for preterm birth risk; however, we only identified a small percentage of doctors who said identifying patients was a barrier (5\%). This small percentage reflects the various provider's practice care models in the community as once patients are identified as high risk for preterm birth, the patients are in majority of cases co-managed with a specialist or referred out for prenatal care with a high risk specialist for the remainder of their pregnancy. This alone becomes a possible barrier for the intervention, as provider shortages may delay the time when the patient is first able to see the specialist provider to discuss possible interventions. Of those surveyed, $15 \%$ of providers identified late entry to care as a barrier which was an interesting observation as it mirrored the chart review findings that identified $15 \%$ of the patients did not receive the intervention due to late initiation of prenatal care. 


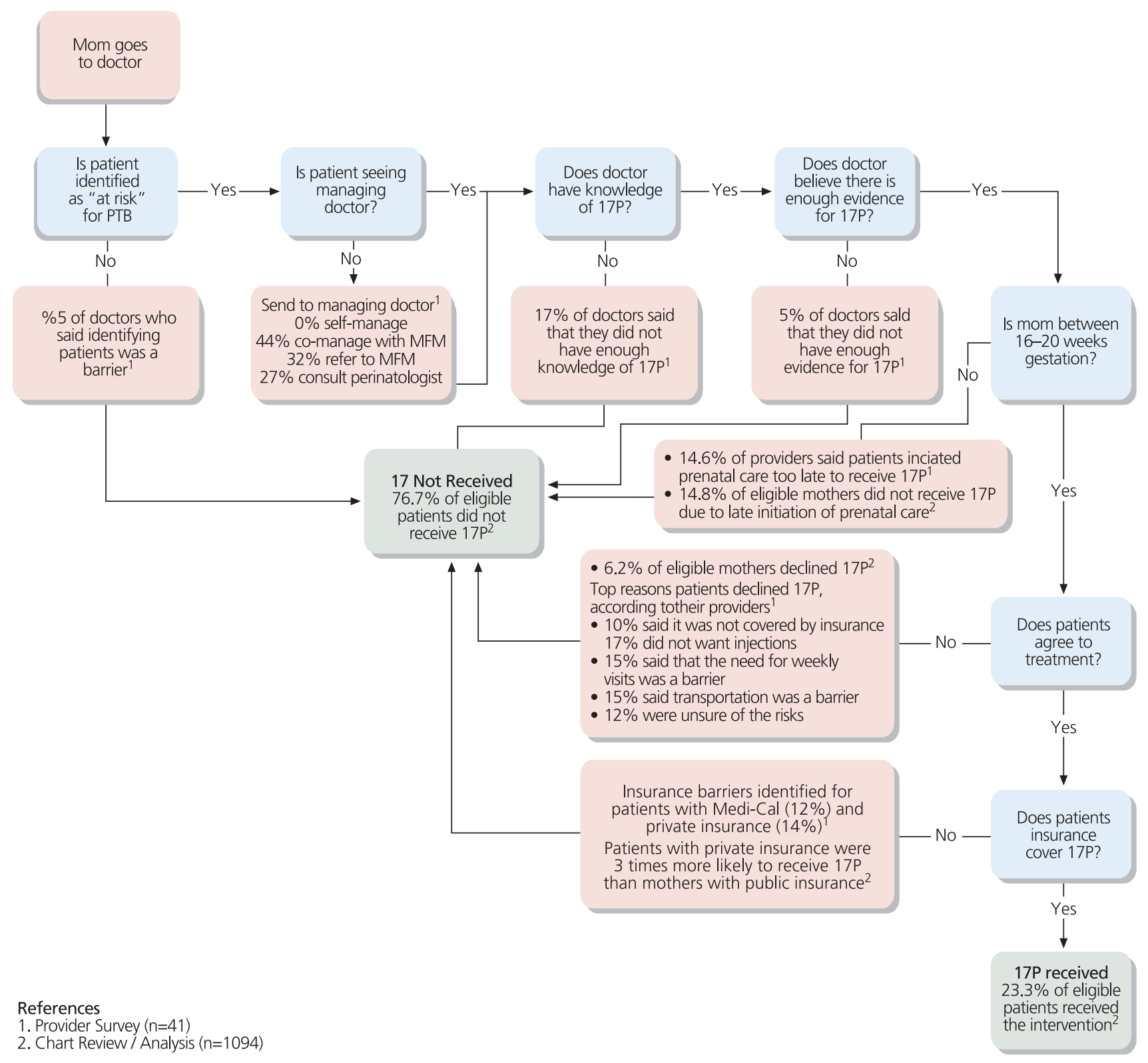

Fig. 2. Health seeking barriers to receiving 17-OHPC.

The most frequently identified barrier in both the provider survey and chart reviews was the lack of insurance coverage for the intervention. This was both a perceived barrier by patients opting out of the treatment when offered, and an actual barrier for patients with public insurance. The perception by providers was that there were more barriers for mothers with private insur- ance, given that some private insurance may not always cover the treatment costs. However, in the end, those with private insurance seem to be able to overcome barriers more than their publicly insured counterparts.

There was also a disparity for mothers with public insurance, even though $17 \mathrm{P}$ intervention is covered. There was a perception of the patients that she would 
not be eligible. Our study results showed that, privately insured patients were more likely to end up receiving the intervention. These insurance barriers identified in our study based on the feedback from our provider group survey results is in contrast to provider barriers reported by Danilack et al., who reported a higher percentage of patients with public insurance received $17 \mathrm{P}$ intervention compared to those with private insurance. ${ }^{[18]}$

There were system level barriers that included lack of insurance coverage, insurance restrictions and non-user friendly processes for obtaining prior authorization for the eligible patients. These barriers negatively influenced provider's level of care in optimizing the implementation of the $17 \mathrm{P}$ intervention. Thus, the majority of providers seemed to have referred these patients out to specialist care and sometimes this may have caused undue delays in the initiation of the intervention.

Chart reviews and patient interviews gave insight into some of the other reasons for patient barriers for the underutilization of $17 \mathrm{P}$. The reasons patients did not receive $17 \mathrm{P}$ as per EMR documentation included patients declining $(6.2 \%)$, missing the eligible GA time frame (14.9\%), insurance declining (2.8\%), some did not meet eligibility criteria $(1.7 \%)$ and patient non-compliance $(1.1 \%)$. There were $73.5 \%$ of eligible patients who had no documented reason for not receiving the intervention in electronic medical records once again pointing to the EMR documentation deficiency.

One of the reasons for patients' tendency to decline the intervention appeared to be influenced by previous pregnancy history. Mothers who had a prior preterm birth near term with shortened length of stay of the neonate in the neonatal intensive care unit or those whose newborns were not admitted to the neonatal intensive care unit were more likely to decline the $17 \mathrm{P}$. This most likely was secondary to a patient's lack of knowledge and awareness that a prior preterm birth not only increases her risk of recurrent preterm birth but that it can occur at a more preterm gestation increasing neonatal morbidity and mortality. Thus, there appeared to be a general lack of perception of the significance of $17 \mathrm{P}$ not only in prevention of recurrent preterm birth but also in the reduction of adverse perinatal or neonatal outcomes. These patient barriers that stem from a lack of knowledge and awareness of the adverse longterm sequelae of prematurity is comparable to the results published by Kalata et al., in 2019 that identified patient's lack of knowledge and awareness as the leading cause for the barriers to the intervention indicating suboptimal counselling by providers regarding the importance of available interventions for prevention of preterm birth. ${ }^{[25]}$

Provider and patient surveys' feedback and electronic medical records documentation also revealed other reasons such as the hassle of weekly injections, cost to the patients and the issues related to transportation and childcare with the weekly clinic visits. These patient barriers identified in our study contrasts with Kalata et al., who reported the time commitment, specifically the length of clinic appointments and concerns about the safety of the 17P injection as main reasons for patients declining the intervention. ${ }^{[2]}$

\section{Conclusion}

Our study confirmed that $17 \mathrm{P}$ intervention for recurrent preterm birth prevention is significantly underutilized in Fresno County, CA, and disproportionately affects patients who have public insurance in addition to a high percentage of patients with inadequate or late prenatal care. The barriers to utilization of $17 \mathrm{P}$ were identified at provider, patient and system levels. One approach to overcome some of these barriers to $17 \mathrm{P}$ utilization would be to increase provider and patient knowledge and awareness of the adverse neonatal outcomes with preterm birth and educate them on the available resources for care and intervention for prevention of preterm birth. One of the solutions to address the system level barriers would be to streamline the insurance authorization process and obtain a buy in from insurance companies for initiating home nurse visits for obstetrical care for the high-risk patients who may have difficulty with making timely clinic visits for care and interventions. ${ }^{[1,24]}$ An organized and systematic approach to addressing these barriers with education to increase knowledge and awareness of long-term adverse sequelae of preterm birth across the community and system can help reduce preterm birth rate.

\section{Implications for Practice and/or Policy}

Preterm birth has a significant negative impact on the public health sector. Preterm birth occurs disproportionately in the lower socioeconomic population group resulting in a significant medical expense burden for the public assisted health insurance system. 
The costs extend far beyond the immediate medical costs as these preterm babies can have long term adverse health issues. Development and implementation of public health policies and strategies at the community level of care can improve outcomes and reduce societal costs. The early recognition and detection of those at risk for preterm birth with initiation of interventions for prevention can help reduce adverse pregnancy outcomes for the high-risk patient populations.

Funding: This work did not receive any specific grant from funding agencies in the public, commercial, or not-for-profit sectors.

Compliance with Ethical Standards: The authors stated that the standards regarding research and publication ethics, the Personal Data Protection Law and the copyright regulations applicable to intellectual and artistic works are complied with and there is no conflict of interest.

\section{References}

1. Center for Disease Control and Prevention. Infant mortality. [Internet]. Washington, DC: CDC; 2019. [cited 2020 July 21]. Available from: https://www.cdc.gov/reproductivehealth/ maternalinfanthealth/infantmortality.htm

2. March of Dimes. The impact of premature birth on society. [Internet]. Arlington, VA: March of Dimes; 2015. [cited 2020 July 21]. Available from: https://www.marchofdimes.org/ mission/the-economic-and-societal-costs.aspx

3. Martin JA, Osterman MJK. Describing the increase in preterm births in the United States, 2014-2016. NCHS Data Brief 2018;(312):1-8. [PubMed]

4. March of Dimes. A profile in prematurity in United States. [Internet]. Arlington, VA: March of Dimes; 2019. [cited 2020 December 19]. Available from: https://www.marchofdimes.org/ peristats/tools/prematurityprofile.aspx? reg=99

5. March of Dimes. Preterm: Fresno city and California, 2014-2018. Internet]. Arlington, VA: March of Dimes; 2020. [cited 2020 December 19]. Available from: https://www. marchofdimes.org/Peristats/ViewSubtopic.aspx? reg=0627000 \& top=3\&stop=60\&lev=1\&slev=5\&obj=1\&cmp=06

6. Eunice Kennedy Shriver National Institute of Child Health and Human Development. What are the risk factors for preterm labor and birth? [Internet]. Rockville, MD: NICHD; 2017. [cited 2017 January 31]. Available from: https://www.nichd. nih.gov/health/topics/preterm/conditioninfo/who_risk

7. Mendez DD, Hogan VK, Culhane JF. Institutional racism, neighborhood factors, stress, and preterm birth. Ethn Health 2014;19:479-99. [PubMed] [CrossRef]

8. Moore ML, Ketner M, Walsh K, Wagoner S. Listening to women at risk for preterm birth: their perception of barriers to effective care and nurse telephone interventions. MCN Am J Matern Child Nurs 2004;29:391-7. [PubMed] [CrossRef]
9. Meis PJ, Klebanoff M, Thom E, Dombrowski M, Sibai B, Moawad A, et al.; National Institute of Child Health and Human Development Maternal-Fetal Medicine Units Network. Prevention of recurrent preterm delivery by 17 alpha-hydroxyprogesterone caproate. N Engl J Med 2003;348: 2379-85. [PubMed] [CrossRef]

10. Committee on Practice Bulletins-Obstetrics, The American College of Obstetricians and Gynecologists. Practice bulletin No. 130: Prediction and prevention of preterm birth. Obstet Gynecol 2012;120:964-73. [PubMed] [CrossRef]

11. Blackwell SC, Gyamfi-Bannerman C, Biggio JR Jr, Chauhan SP, Hughes BL, Louis JM, et.al. 17-OHPC to prevent recurrent preterm birth in singleton gestations (PROLONG Study): a multicenter, international, randomized double-blind trial. Am J Perinatol 2020;37:127-36. [PubMed] [CrossRef]

12. FDA, SMFM and ACOG respond to PROLONG study results: Does IM 17-OHPC impact preterm delivery? [Internet]. ObG Project website; 2021. [cited 2020 July 21]. Available from: https://www.obgproject.com/2019/10/25/prolong-studyresults-and-the-smfm-response-does-im-17-ohpc-impactpreterm-delivery/

13. Society for Maternal Fetal Medicine (SMFM). SMFM responds to the FDA's proposal that Makena and generic equivalents be withdrawn from the market. [Internet]. Washington, DC: SMFM; 2020. [cited 2020 December 16]. Available from: https://s3.amazonaws.com/cdn.smfm.org/media/2543/Makena, 10.5.pdf

14. Society for Maternal Fetal Medicine. SMFM Statement: Response to EPPPIC and considerations for the use of progestogens for the prevention of preterm birth. [Internet]. Washington, DC: SMFM; 2020. [cited 2020 March 30]. Available from: https://s3.amazonaws.com/cdn.smfm.org/ publications/383/download-d37b137ec0d26f8c268933 be6800dd27.pdf

15. EPPPIC Group. Evaluating Progestogens for Preventing Preterm birth International Collaborative (EPPPIC): metaanalysis of individual participant data from randomised controlled trials. Lancet 2021;397(10280):1183-94. [PubMed] [CrossRef]

16. Central Valley Health Policy Institute. Determinants of infant mortality in Fresno County. [Internet]. Fresno, CA: California State University; 2015. [cited 2020 July 20]. Available from: http://www.fresnostate.edu/chhs/cvhpi/documents/AAIM\%2 01-7-2016\%20Final.pdf

17. Yee L M, Liu LY, Sakowicz A, Bolden JR, Miller ES. Racial and ethnic disparities in use of 17 -alpha hydroxyprogesterone caproate for prevention of preterm birth. Am J Obstet Gynecol 2016;214:374.e1-6. [PubMed] [CrossRef]

18. Danilack V, Hosmer J, Littman L, Frost J, Clyne A, O’Brien J. Provider perceived barriers to $17 \mathrm{P}$ use to prevent recurrent preterm births [21E]. Obstet Gynecol 2018;131:57S-58S. [CrossRef]

19. Bousleiman SZ, Rice MM, Moss J, Todd A, Rincon M, Mallett G, et al.; Eunice Kennedy Shriver National Institute of Child Health and Human Development Maternal-Fetal Medicine 
Units Network. Use and attitudes of obstetricians toward 3 high-risk interventions in MFMU Network hospitals. Am J Obstet Gynecol 2015;213:398.e1-11. [PubMed] [CrossRef]

20. Orsulak MK, Block-Abraham D, Gee RE. 17--hydroxyprogesterone caproate access in the Louisiana Medicaid population. Clin Ther 2015;37:727-32. [PubMed] [CrossRef]

21. Armstrong J, Meis P. Clinical, family, and cost outcomes of preterm births: An overview of the problem and prevention opportunities. J Clin Outcomes Management 2007;14:547-53.

22. Baker E, Hunter T, Okun N, Farine D. Current practices in the prediction and prevention of preterm birth in patients with higher-order multiple gestations. Am J Obstet Gynecol 2015;212:671.e1-7. [PubMed] [CrossRef]
23. Sannisto T, Kosunen E. Initiation of postpartum contraception: a survey among health centre physicians and nurses in Finland. Scand J Prim Health Care 2009;27:244-9. [PubMed] [CrossRef]

24. Cross-Barnet C, Benatar S, Courtot B, Hill I, Johnston E, Cheeks M. Inequality and Innovation: Barriers and Facilitators to $17 \mathrm{P}$ Administration to Prevent Preterm Birth among Medicaid Participants. Matern Child Health J 2018;22:160716. [PubMed] [CrossRef]

25. Kalata M, Teter K, Wagner L, Swarr V, Witzeman K. Understanding barriers to uptake of 17 alpha-hydroxyprogesterone caproate (17-OHP) in women with history of preterm birth. J Matern Fetal Neonatal Med 2021;34:541-6. [PubMed] [CrossRef]

This work is licensed under the Creative Commons Attribution-NonCommercial-NoDerivs 4.0 Unported (CC BY-NC-ND4.0) License. To view a copy of this license, visit http://creativecommons.org/licenses/by-nc-nd/4.0/ or send a letter to Creative Commons, PO Box 1866, Mountain View, CA 94042, USA.

Publisher's Note: The content of this publication does not necessarily reflect the views or policies of the publisher, nor does any mention of trade names, commercial products, of organizations imply endorsement by the publisher. Scientific and legal responsibilities of published manuscript belong to their author(s). The publisher remains neutral with regard to jurisdictional claims in published maps and institutional affiliations. 